\title{
АМПЛИТУДНО И ФАЗОЧАСТОТНЫЕ ХАРАКТЕРИСТИКИ МАГНИТООПТИЧЕСКОГО МОДУЛЯТОРА НА БИМОРФНОМ ЭЛЕМЕНТЕ В РЕЖИМЕ МАГНИТОМЕХАНИЧЕСКИХ КОЛЕБАНИЙ
}

\author{
ЛИНЧЕВСКИЙ И. В. ${ }^{1}$, СКРИПЕЦ А. В. ${ }^{2}$ \\ ${ }^{1}$ Нацииональный технический университет Украинь \\ «Киевский политехнический институт», \\ Украина, Киев, 03056, пр-т Победь 37 \\ ${ }^{2}$ Национальный авиационный университет, \\ Украина, Киев, 03058, пр-т Космонавта Комарова, 1
}

\begin{abstract}
Аннотация. Приведены теоретические расчеты пространственного распределения амплитудно- и фазочастотных характеристик вектора Стокса для магнитооптического модулятора на основе магнитооптического кристалла в составе биморфной пластины прямоугольной формы в режиме основной моды магнитомеханических колебаний. Геометрия магнитных полей и направление распространения света относительно кристаллографических осей обеспечивают возникновение линейного и квадратичного по магнитному полю магнитооптических эффектов. Показано, что за счет фазовых задержек в напряжениях, возникающих в биморфной пластине в области частот основной акустической моды, элементы вектора Стокса выходного излучения приобретают пространственно зависимые изменения амплитуды в пределах $10 \%$ и фазы в пределах $\pi$
\end{abstract}

Ключевые слова: магнитооптический модулятор; эффект Фарадея; биморфная пластина; магнитомеханический резонанс

\section{ВВЕДЕНИЕ}

Магнитооптический модулятор света на биморфном элементе позволяет получать двумерное распределение угла поворота плоскости поляризации по сечению пучка света [1]. Такое распределение обеспечивается за счет изменения намагниченности магнитооптического кристалла (МОК) при деформациях сдвига в биморфной конструкции модулятора. С другой стороны, для обеспечения условий магнитомеханических колебаний в биморфной структуре магнитооптический кристалл поме- щается в постоянное (поляризующее) и переменное магнитные поля заданной частоты. При этом направление магнитных полей должно быть параллельным плоскости биморфной пластины. В результате свет, проходящий через магнитооптический кристалл, приобретает постоянную и переменную эллиптичность, которая изменяется с частотой переменного магнитного поля. Таким образом, в рассматриваемом модуляторе помимо модуляции света за счет эффекта Фарадея присутствует поляриза-

* Работа выполнена в рамках научно-исследовательской работы г/p № 0114u003916.

Электронный вариант статьи: http://radio.kpi.ua/article/view/S0021347015080063

() Линчевский И. В., Скрипец А. В., 2015 